\title{
Major Policy Challenges in Trade and Finance in the Asia-Pacific Region"
}

\author{
KIHW'AN KIM \\ Chairman. Seokl Financial Forum
}

By every measure, the Asia-Pacific region is extremely important not only for the world economy, but for Korea as well. Given this importance, the paper identifies two major policy issues to be addressed by countries in this region. In trade, the recent proliferation of regional trading arrangements poses a serious threat to the continuation of economic growth in the region. In finance, the lack of capacity of the financial system in East Asia in particular has given rise to an unhealthy portolio of financial assets held by East Asian countries. The policy suggestions by the author include the strengthening of the WTO discipline on regional trading arrangements and closer financial cooperation among countries in the Asia-Pacific.

Keywords: Asia-Pacific region, multilateral trading system, preferential arrangements, APEC, trade and finance

This article was modified from a speech the authot delivered at the Graduate School of International Studies, Ewha University on November 7, 20033.

Direct all correspondence to Kihwan $\mathrm{Kim}_{\mathrm{r}}$ Chairman, Scoul Financial Horum, Goldman Sachs (Asia) L.L.C., $21^{\text {st }}$ Floor, HungKuk Life Insurance Building, 226 ShinMun $\mathrm{Ro} 1 \mathrm{Ga}$, Chong Rn-Gu, Seoul, Korea; Tel: 82-2-3789-1820; E-mail: kihwan $(\bar{a}: \mathrm{gs} . \mathrm{com}$ 


\section{INTRODUCTION}

$\mathrm{D}$

efined as the geographic region covered by the member economies of the

Asia-Pacific Fconomic Cooperation (APEC), the Asia-Pacific region is the most important economic: region in the world. Currently, the region is home to the two largest conomies in the world. It accounts for rouglly 60 percent of the global gross domestic product (GDP) and some 47 percent of global trade. In addition, compared to other tegions of the world, the Asia-Pacific region is very dynamic. The two most rapidly growing, large economies, namely China and the United States are to be found in this region. Both economically and politically, the Asia-Pacific region is very important to Korea as well. This region is the destination for approxirnatcly 71 percent of Korca's exports and some 75 percent of diect foreign investment in Korea comes from this region. The four tnajor powers that have dominant influence on the peace and stability of the Korcan peninsula, namcly the UJ.S., Jayan, China and Russia, are locared in this region.

Given the strategic importance of this region, the purpose of this paper is twofold: first, to identify major policy challenges to be met by countries in this region in the field of trade and finance and second, to suggest how these challenges are to be met.

\section{PRIME ISSUES IN TRADE}

In order for the Asia-Pacific region to maincain its economic dynamism, it is essential that the trade policy regime in this region remain healthy. Particularly for relatively small cconomies such as Korca, the optimal trade regime is the onc based on an unqualified commitment made by all countries in the region to an open multilateral trading system with no discrimination. However, the ways in which many countries in this region have tried to expand their trade in recent years have signiffantly diverged from this multilateral paradigm.

\section{Shifts toward Preferential Trading Arrangements (PTAs)}

Until about 1998, countries in the Asia-Pacific region for the most part pursued policies in favor of strengthening the multilateral regime based on (iATT/WTO principles. This was best illustrated in the open regionalism embodied in the Bogor Declaration of 1944. Unfortunately, however, within a lew years of the Bogor Declaration, a significant change in policy began to occur. While it is true most of the countries in this tegion still prefer a multilateral approach to trade and invest ment liberalization, vistually all of them have now begun to resort to various forms of preferential regrional and sub-regional trade arrangements as well. Today, there are more than 30 different initiatives in this region for such arrangements. Some have already been conduded, 
with some being negotiated while still others ate being contemplated. Examples include the so-called free trade areas (FrAs) between China-ASEAN, Japan-ASEAN, Japan-Singapore, Australia-Singapore, U.S.-Australia, U.S.-Singapore, U.S.-Thailand, Korea-Chile and Korea-Japan. In short, over the pase few years, this region has been in a rush to form bilateral, plurilateral and other sub-regional preferential arrangements in a marked departure from its earlier orientation toward open regionalism and mulrilateralism.

Of course such a dualistic approach had not been unheard of even before the Bogor Declararion. A case in point was the conclusion of the North American Free Trade Agreement (NAFTA) involving, at first, the United States and Canada, and later Mexico. Even at the time when NAFTA was concluded, however, many in the region hoped discriminatory impacts of this particular preferential trading arrangement could be minimized by bringing NAFTA westward to cover virtually all of the economies in the Asia-Pacific, including those in East Asia. Neither has this happened to this day, nor is there a likelihood of this happening in the near future. For one thing, the U.S. currently appears to be more interested in extending NAFTA into the geographic region covered by the Free Trade Area of the Americas (FTAA) than extending NAFTA across the Pacific.

\section{Factors at Work}

In any event, there is little question that NAFTA and other preferential arrangenents already concluded, being negotiated or being contemplaced by countries in this region, are motivated in large measure by the desire of these countries to look for alternatives to the liberalization of trade and investment under the GATT/WTO framework. Many of them have experienced a great deal of frustration in liberalizing their trade and investment through the WTO process on account of the excessive arnount of time it requires, due to fundamental flaws in the structure of the process itself.

There is yet another important reason why the shift to preferential regional, sub-regional or bilateral arrangements has occurred. One may recall that in the early 1990s, former Malaysian Prime Minister Mahathir bin Mohamad was keen to promote what he called the East Asian Economic Caucus, which amounted to an advocacy of a preferential trade agreement (PTA) encompassing East Asian economies. As long as these economics did well, especially in terms of overall growth and investment under the multilateral system, Mahathir's idea had only limited appeal.

But this changed rather dramatically in the course of the Asian financial crisis of 1997-1998. When the financial crisis first started in Thailand in the summer of 1997, the U.S. did not show much interest in assisting the country directly. Instead, the U.S. allowed the International Monetary Fund (IMP) to do what it could to help Thailand. The U.S. policy response was similar when the financial crisis spread to Indonesia and Malaysia. When it became obvious that many East Asian countries were about to succumb to the contagion of the crisis and that the usual IMF policy 
prescription was not appropriate for Asian countries, the Japanese government proposed establishing an Asian Monetary Fund (AMF). This idea was, however, altogether rejected by the U.S. and it was only when the financial crisis finally spread to Korea that the U.S. showed a willingness to get directly involved. This seemingly inconsistent policy response by the U.S. caused many countries in Asia to doubt whether the U.S. really cared about problems in East Asia. This, in turn, greatly weakened the willingness, embodied in the Bogor Declaration, on the part of Asia-Pacific economics to work jointly toward an open, global, and multilateral trading system through APEC.

Other developments in this region in recent years have had further adverse impacts on this willingness. At the first ASEAN+3 summit held in Manila in 1999, an agreement was reached to launch an East Asian vision group responsible for mapping out the future course of development for ASEAN +3 . The vision group soon issued its report recommending the formation of a Free Trade Area of Fast Asia (FTAEA). Another case in point was the offer from China to cnter into a free trade arca with ASEAN. Yet another case is the eagerness on the part of Japan to form a bilateral FTA with South Korea and what Japan calls a comprehensive economic partnership with ASEAN countries.

The reasons for such a tilt toward preferential arrangements are not, of course, to be sought entirely within the region. For one thing, as already noted, many economies in the region have been very frustrated with the slow progress in libcralization achieved through the multilateral process. The Uruguay Round of negotiations, launched in 1986, was expected to last no more than three years but it took altogether seven years to conclude. For another, preferential trading arsangements have proliferated globally at an amazing speed. Today, there are no less than 300 PTAs in the world and more than one half of them have come into being since 1990. As PTAs have increased globally, many economies in the region fear that unless they too become part of the worldwide trend toward preferential arrangements, they will be left out completely.

\section{Deplorable Comsequences}

Whatever the reasons, the changes in policy posture in favor of preferential arrangements have deplorable consequences. There have been debates among economists on whether preferential arrangements represent a building or stumbling block toward the liberalization of world trade. ${ }^{1}$ While one often hears that under certain conditions, prefercntial trading artangements can be a building block, this argument is not very convincing. The catch here is what is meant by "ecrtain conditions." They include the consistency of an arrangement with WTO principles, the full coverage of products under the arrangement, and the degree and duration of barriers against non-members.

For an excellent summary of discussions on whether preferential trading arrangements are either stumbling or building blocks, see Sxollay (2003, 1-2). 
Most of the arrangements either concluded of under discussion, however, fail to meer one or more of these conditions. Thus, one can conclude that with few exceptions, preferential trading arsangements so far represent a scumbling block rather than a building block. In other words, in the world of a growing proliferation of preferential arrangements, overlapping and inconsistent rules and disciplines are unavoidable. Moreover, combined with the complex set of rules of origin, this in turn creates what Jagdish Bhagwati has called the "spaghetti bowl" effect, which hampers the growth of trade globally by raising the cost of transactions everywhere.

The problems are compounded if the limited resources of individual governments to negotiate and administer trade agreements are diverted away from multilateral negotiations. Furthermore, preferential trade arrangements become stumbling blocks especially if and when they give rise to intcrest groups that benefit from such arrangements and oppose liberalization through the multilateral process.

\section{Danger of a Tri-Polar World}

There is yet another serious problem associated with the rush toward preferential arrangements. If East Asian countries continue on the current path toward preferential arrangements and North Americs continues to make efforts to expand NAFTA into FTAA, there is a possibility for two "mega-blocs" to emerge in the Pacific, i.e., a large free trade area on the western rim in the form of ASEAN+3 and the other large free trade area on the eastern rim in the form of the FTAA. This development would give rise to a tri-polar world, where the EU, FTAA and East Asia groupings are the three key blocs. The question that should be asked by everyone is whether a world split three ways, as compared to a world split two ways would be desirable. The answer is definitely no. Game theory says that any situation involving three major players is inherently unstable, because each of the players always fears that the other two will gang up together. This generates a great deal of insecurity and induces all players to make precmptive strikes in order to secure tactical advantage. ${ }^{2}$

It is important to note that this inference is not just theoretical. The inherent instability of a tri-polar world has shown to be true throughout human history. For example, before World War II, the world was split into three major blocs: the Anglo-American bloc led by the United States and the United Kingdom; the European bloc by Germany; and the East Asian bloc by Japan. As each bloc made its first move to obtain tactical advantage, the relationships among the three blocs quickly deteriorated, leading to World War II.

\section{Hub-and-Spoke Arrangement: No Good Answer Eitber}

There is yet another problem associated with preferential trade arrangements in

Fred Bergsten's view on this point is the same as mine. See Bergsten (2000, 14). 
the region that should be noted. According to some observers, 3 fortunatcly or unfortunately, the possibility of East Asia emerging as a single trade bloc in the foresccable future has become somewhat diminished by a recent development. As China has bid for a China-ASEAN frec trade arrangement, so has Japan bid for a similar arrangement with ASEAN in the name of a comprehensive economic partnership. What such developments seem to augur is a possibility wherchy China and Japan play the role of hubs while other individual countries or economies scrve as spokes. This hub-and-spoke arrangement has its drawbacks. A hub country normally enjoys a superior bargaining position over spoke countrics, thus gaining opportunities to trade on favorable terms with spoke countries. A spoke country, however, has to bear a disadvantaged bargaining position. It will have to forcgo the opportunity to trade on equal terms with other spoke countries unless it negotiates with every other spoke country individually.

\section{POLICY PROBLEMS IN THE FINANCIAL AREA}

Let us now discuss major policy challenges in the field of finance for the Asia-Pacific region. Apart from the problems associated with the proliferation of regional, sub-regional and bilateral trade artangements, there are serious problems with financial flows within this region. To be sure, since the Asian financial crisis of 1997-1998, the economits in East Asia in particular have come together to strengthen cooperation amougst them. The Chiang Mai Initiative (CMI) is a case in point; it represents an arrangernent whereby central hanks in the region try to help each other through currency swaps should a party or parties to the arrangement face liquidity shortagc. But we should not overestimate the practical significance of this arrangement. It is true that as of today, the aggregate amount of liquidity that could be mobilized in case of another crisis under the CMI is US $\$ 32.5$ billion. One should not, however, think that the whole of this amount would readily be available to a particular country in a crisis because the structure of the arrangement remains bilateral tather than multilateral. Moreover, Japan's efforts to make addicional resources available for the same purpose in the form of the Miyazawa Plan have not gone very far. For example, the maximum amount of bilateral swap that Japan has commitced to provicte to Korea and Malaysia under the plan is only US $\$ 7.5$ billion.

\section{Is Anotber Financial Crisis Likely in East Asia?}

'Today, East Asian countries are known for their enormous amount of foreign exchange reserves. Japan, Chima, Taiwan and Korea are currently the four largest holders of reserves in the world. Together they account for over three-fifths of world reserves.

Scollay $(2003,4)$ notes that the emergence of mega blocs in the Asid-Pacific region is by no means a forcgone conclusion 
Based on such facts, some observers argue that today there is little chance that East Asia will nun into a currency crisis similar to that of 1997-1998. It is not certain that one can be so sanguine. For onc thing, the pattern of financial tlow in the Asia-Pacific is not very healthy. Currently, East Asia as a whole is a net saving surplus region whereas North America is a net saving deficit region. In other words, in net terms, financial resources flow from East Asia to North America, primarily to finance the budgetary deficits of the U.S. This pattern is an anomaly to say the least. East Asia as a whole is still a developing region with a higher marginal productivity of capital, but its savings are not used to accelerate devclopment in the region and instead, of all things they are used in North America to help finance U.S. budgetary deficits.

\section{U.S. Pressure on Asian Economies to Appreciate Their Currencies}

There is yet another problem in this area. Due primarily to the prepondetant reliance of global trade on the U.S. dollar as the medium of settlement and the lack of capacity for the financial system in East Asia to intermediate effectively becween savers and investors, East Asian economies are compelled to import safe but low-yield dollar-denominated assets such as U.S. treasury bills and inter-bank deposits on the one hand, and export risky but high-yielding assets such as equities and bonds on the other.'

One of the very serious problems with this pattern of asset holding is that most of the dollar assets are no longer as safe as once believed. This is especially true now that with increasing L.S. budgetary as well as current account deficits, the value of the dollar cannot help but decline. To make matters worse, it is the policy of the Bush Administration to put pressure on Asian countries to appreciate their currencies vis-à-vis the dollar. The question one should ask is: What will be the consequence of this policy? One thing is certain. With the prospect of the value of the dullar declining, Asian holders of U.S. dollar-denominated assets will sooner or later be induced to move out of those assers. This has the potential nor only to wreak great havo in the international financial markets, but also to cause great financial difficulties for many non-financial firms in Asia, and those in China in particular.

If current U.S. efforts to appreciate Asian currencies succeed, Asian economies will be subjected to a high degree of deflationary pressure. With deflationary pressure, 5 the economic recovery currently underway in Asia may well be short-lived. Indeed there is now a real possibility that Asian economies will suffer a prolonged period of stagnation, just as the Japanesc economy did in the late 1980 s after Japan agreed to the Plaza Accord in 1985.

\footnotetext{
As far as the author con tell, Andrew Crockets is che first witer to call attention to tiis problem. For more details, see Crockert (2(1)2).

For a critical atalysis of the currenc U.S. cffort to appreciate Asiat currenctes, sec MeKinnon and Schnabl (2003).
} 
One should note that as far as dealing with trade and current account deficits is concerned, U.S. policymakers do not seem to have learned any lessons from their experiences in the $1980 \mathrm{~s}$. There is no question that the basic cause for U.S. current account deficits in the 1980 s was the shortage of its domestic savings relative to its investment. Nonetheless, U.S. policymakers chose to blame the absence of "a level playing field" in trade for the growing U.S. deficits. One cannot but hope that the current efforts on the part of the U.S. to appreciate Asian currencies will not have the same kind of results for the whole of Asia that similar efforts had for Japan earlier.

\section{POLICY SUGGESTIONS}

The question to be raised at chis point is: What should countries in the Asia-Pacific region do with the many problems resulting from the current approaches to regional trade and finance?

First and foremost, there is a need to do something abour the proliferation of regional, sub-regional and bilateral trade arrangements. This is particularly important for a country like Korea. In this connection, however, one cannot help but be reminded of a dilemma often noted by trade economists in the form of a comparison berween preferential trading arrangements and strect gangs. The effects of street gangs are pernicious. But if they are operating in one's neighborhood, the safest course of action may well be to join them. However, many small countries, especially countries like New Zealand, ate not very well positioned to take this course of action. Being small, they are not attractive partners for any trading arrangements. In addition, if their exports are concentrated in sensitive sectors such as agriculture, as is the case in New Zealand, they will be even less attractive as a partner. Thus, the question one has to come back to is: How should countries work together to make multilateralism effective?

Most ubviously, there is an urgent need to look into the basic causc of the breakdown of the ministerial talks in Cancun, Mexico last year. The breakdown reveals that the most serious obstacle to further progress with the Doha Development Agenda (DDA) lies precisely in the protectionist attitude of some industrialized countries, including Korea, toward agriculture. This being the case, all of the countries would do well to concentrate on changing this very attitude by urging the governments concerned to do away with the policy of agricultural subsidies linked to production and to adopt ones designed solely to increase the income of farmers. Subsidies linked to income would have little distortion in the allocation of rcsources, thus having minimal adverse effect on the optimal pattern of world trade. In addition, income-linked subsidies would make it transparent as to how much burden an economy actually bears duc to agricultural protectionism.

Something should also be done with regard to the unrealistic deadline for the 
conclusion of negotiations under the DDA. Even without the Cancun setback, the January 1, 2005 deaclline for the DDA Round was unrealistic in the first place. In the long run, a new rule for making decisions within the WTO should also be introduced. The global trading community simply cannot allow countries with minimal interest at stake in world trade to dictate the process of future negotiations for political objectives. Also, greater efforts are needed to further develop and clarify WTO rules on regional trade arrangements. When it comes to regional trade arrangements, WTO rules are for the most part ambiguous and unenforceable.

Second, there is a need to reaffirm the goals and principles of APEC. APEC is about reduction of barriets to trade and investment on a non-discriminatory basis. The Bogor goal of achieving free trade for developed countries by 2010 and for developing countries by 2020 is as valid today as when it was first adopted. Similarly, the continued efforts of APEC to lower trade and investment barriers are the best defense against the discriminatory impact of the protiferation of regional and bilateral trade arrangetnents. APEC members should also try to exercise theit decisive leadership for the Doha Round as they had done before in connection with the Uruguay Round at the critical juncture of negotiations. In this regatd, the APEC Ministerial and Leaders' meetings held in Bangkok in October 2003 were a disappointment because both Ministers and Leaders failed to go all the way in providing decisive leadership. To show the world that they are serious about the success of the Doha Round, they should have come up with a concrete new initiative rather than simply remind the world how important it is for the world to conclude the Doha Round successfully.

Third, for APEC to become more effective in providing leadership on such matters as the Doha Round, it should strengthen its own identity and organizational structure as well. Gareth Evans, while he was still the Minister of Foreign Affairs and Trade of Australia, observed that APEC, which stands for Asia Pacific Economic Cooperation, is a series of adjectives in search of a noun. In other words, to this day, no one is clear whether APEC is just a forum or an organization where agreements reached are binding on members. This fundamental ambiguity about the nature of the organization should be remedied. In short, APEC should become an organization with binding obligation and enforcement powers.

Fourth, it is true that APEC members have begun to pay attention to the need for increasing cooperation among its members since the 1997-1998 crisis in the financial area. However, progress in this area remains highly limited. APEC Finance Ministers have yet to come up with a meaningful program for cooperation among APEC economies in their field. To be sure, they have endorsed the development of bond markets in the APEC region, but one should note that the markets they have in mind ate for bonds denominated in U.S. dollars. But this scheme fails to address the "double mismatch" which was the basic cause of the 1997-1998 crisis. This deplorable state of affairs reflects the lack of actionable ideas as much as anyching else. What this implies, among others, is that such non-governmental organizations as the Pacific Economic Cooperation Council (PECC) should accelerate their work on such issues 
as monetary and financial cooperation in the APEC region. Priorities in this regard should be on how to develop regional markers for bonds issued in local currencies and how to increase the risk management capacities of financial institutions in this region.

Before concluding, two additional points are in order. For APEC to become more effective in addressing regional trade and financial problcms, non-governmental organizations such as PECC that support the work of APEC should become more effective as weil. In the opinion of many, there are altogether too many non-governmental organizations basically trying to achieve the same objective, namely, greater integration of Asia Pacific cconomies based on market principles. In addition to PECC, there are Pacific Basin Fconomic Council (PBEC); APEC Business Advisory Council (ABAC); and the annual $\mathrm{CEO}$ Summits sponsored by various organizations. These organizations would do well to better coordinate their activities. Better still, they should merge their activities if not theit organizations.

The orher point has to do with the critical role of the U.S. It is useful to remind ourselves that the basic cause of such problems as the proliferation of preferential trading arrangements is the loss of momentum for trade and investment liberalization through the GATT/WTO framework. This in turn has much to do with the failure on the part of the U.S. to provide strong leadership to further strengthen the WTO. It may be recalled in this regard that it was the L.S. leadership more than anything else that has brought about the evolution of the GATT/WTO system to what it is today. Since the end of the Cold War, however, incentives on the part of the U.S. to provide strong leadership in this area have markedly diminished. In addition, relatively speaking, the strength of the U.S. to call the shots on world affairs, including trade, has weakened. Moreover, since September 11, the U.S. is increasingly occupied with the war on terrorism. If this judgment is correct, what the world needs today is for several countries to help the U.S. continue to provide strong leadership for the multilateral trading system. One way to do so is to work together with the U.S. on issues of great interest to itself, including the war on terrorism. A good place to do so will be wichin APEC itsclf.

In summary and conclusion, the proliferation of regional trade arrangements and the pattern of financial flows in the APEC region as well as insufficient financial cooperation in the tegion present major challenges. However, there arc ways to meet these challenges, especially if countries or economies in the region renew their efforts to work together. 


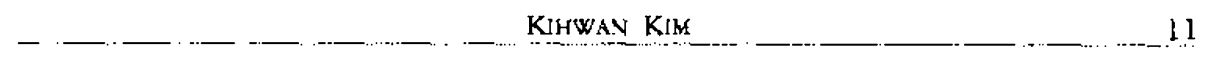

\section{REFERENCES}

Bergsten, Fred. 2000. The New Asian Challenge. Working Paper 00-4, International Inscitutc of Economics, Washington, D.C., March 2000.

Crockert, Andrew. 2002. Capital Flows in East Asia since the Crisis. Speech delivered at the Meeting of Deputies of the ASEAN +3 in Beijing, October 11, 2002.

Kim, Kibwan. 2002. New Trends Towards Preferential Trade Arrangements in East Asia: An Linmixed blessing? Asia Perspectives 5 (1): 11-14.

McKinnon, Ronald and Schnabl, Gunther. 2003. The East Asian Dollar Standard, Fear of Floating, and Original Sin. Working Paper 03001 , Department of Economics, Srantord University, September 2003.

Scollay, Robert. 2003. New Zealand and the New'Trend to Preferential Trading Arrangements in Asia-Pacific Region. An Informal Paper, September 2003. 